\title{
Navigating the impact of globalization on bank efficiency in China
}

\begin{abstract}
The paper provides for the first time empirical evidence on the impact of economic globalization on bank efficiency in a developing economy. Using the data envelopment analysis method, we compute the efficiency of the Chinese banking sector during 2000-2007. The empirical findings suggest that the inefficiency of the Chinese banking sector stems largely from scale rather than pure technical inefficiencies. Examining different components of economic globalization, we find that greater economic integration through higher trade flows, cultural proximity and political globalization have significant and positive influence on bank efficiency levels. The empirical findings suggest that liberalization (restrictions) of the capital account exerts a negative (positive) influence on bank efficiency levels in China.
\end{abstract}

Keyword: Bank efficiency; Data envelopment analysis; Economic globalization; Panel regression analysis 